\title{
Multinational Tax Base Erosion Problem of the Digital Economy
}

\author{
Wei Peng \\ School of Economics, Jinan University, Guangzhou, China \\ Email:281458760@qq.com
}

Received 29 February 2016; accepted 22 March 2016; published 25 March 2016

Copyright () 2016 by author and Scientific Research Publishing Inc.

This work is licensed under the Creative Commons Attribution International License (CC BY). http://creativecommons.org/licenses/by/4.0/

\begin{abstract}
Recently, Amazon and Google and other large multinational companies are reported that they use changing corporate structure to avoid tax. This behavior caused widespread international concern. Many multinational companies use digital economy transactions, and take advantage of international tax loophole to erode basic tax. This emerging trading pattern is a huge challenge to national tax authorities. Thus, researching the tax mechanism of Transnational Corporations in the digital economy, a better understanding of the behavior of multinational tax avoidance is important to our country. This paper analyses the digital economy trade transaction characteristics, and points out the cause of the tax erosion in the area of digital economy; then combines with characteristics of the tax system China, discusses on measures taken by China to deal with the tax avoidance in the digital economy.
\end{abstract}

\section{Keywords}

Digital Economy, Base Erosion, Profit Transfer, Tax Collection and Administration

\section{Introduction}

With the rapid development of digital economy, improving information and communication technologies reduce the cost of communication market transactions, and also promote the development of new products such as data services researching. These technologies changed the way of modern business and multinational transactions. Since the 1990s, with the rapid development of information technology and the popularity of Internet, international trade has built up a new way of virtual transactions. The digital economy has changed the business model and integrated the global value chain. At the same time digital economy also brought huge impact to the traditional economic structure and tax rules. The digital economy has become the tax base erosion and profit transfer disaster area. In the past, cross-border business activities need to constitute a physical presence as the tax basis 
of assessment, but the digital economy has weakened the link between economic activity and the specific location. Enterprise servers use Internet connection of digital products and services to conduct transactions. As the Internet site and the server itself don't constitute a physical junction point. This will inevitably lead net income tax countries to lose tax income. Meanwhile, as digital transaction have occult and virtualization features, national tax authorities are difficult to identify the true identity of the transaction tax status and body. And it is difficult to determine the appropriate tax liability and tax treatment for tax authorities. Multinational companies easily use these features in the low tax countries and regions through the structure of the company to achieve profit transfer, and do not violate the international tax law. The tax laws of various countries have not yet been synchronized with the economic globalization and the number of transactions, so the phenomenon of tax evasion is very serious.

Digital economy can use the network transactions to avoid the establishment of tangible premises anywhere. The regulation of e-commerce is quite stretched. To deal with the digital economy and the tax base eroded profit transfer issues require joint action by many systems, such as transfer pricing, harmful tax, mixed mismatch, the controlled foreign company regime, etc. It is difficult to separate these systems. In China, in view of the special tax and regulatory environment, the use of hybrid mismatch arrangements to tax avoidance is not common; and about to prevent harmful tax together with the need for international multinational reach, harmful tax mixing mismatch is not within the scope of this article. The international organizations and national tax authorities are actively exploring policy issues related to the digital economy legal countermeasures. Started in June 2012, G20 finance ministers and central bank governors have coped with the tax base erosion and profit transfer through international cooperation.

\section{The Characteristics of the Digital Economy Trade}

Digital economy can use the network transactions to avoid the establishment of tangible premises anywhere, not restricted by national boundaries and other geographical areas. The monitoring of e-commerce makes the world quite stretched. To deal with the digital economy and the tax base eroded profit transfer issues, which require joint action by many systems, such as transfer pricing, harmful tax, mixed mismatch, the controlled foreign company regime, etc. It is difficult for their individual policies. In China, in view of the special tax and regulatory environment, the use of hybrid mismatch arrangements to avoid tax is not common in our country, and to prevent harmful tax together with the need for international multinational reach, harmful tax mixing mismatch is not within the scope of this article. The international organizations and national tax authorities are actively exploring policy issues related to the digital economy legal countermeasures. Started in June 2012, G20 finance ministers and central bank governors have jointly coped with the tax base erosion and profit transfer through international cooperation.

Digital economy is traders rely on the use of electronic devices and network approach behavioral technology transactions, which are the essential characteristics of digital goods and services, business management and economic integration of trading activities. Digital economy relies heavily on intangible assets. Overall, the digital economy spawned the following main business model: 1) e-commerce: using the Internet to sell goods or services, including B2B (business to business), B2C (business to consumer), $\mathrm{C} 2 \mathrm{C}$ (consumer to consumer); 2) payment services: the buyers and sellers to provide intermediary services, credit card envelope or real-time bank transfers services; 3 ) online advertising: using the Internet as a medium to deliver customer marketing information; 4) cloud computing: refers to the use of shared resources and virtual resources to provide services such as storage, computing, digital management and other services. Some of these business models generate no profits, and they usually get income in the following ways: service revenue, advertising, subscription fees, the transfer of the concession to a third party, the sale of user data.

Digital economy is different from the traditional way of doing business in the rapid development. Digital economy has increasingly prominent feature. Details as follows:

- Liquidity: 1) Liquidity of intangible assets, intangible assets can be easily transferred between the enterprise and the distribution and lead to the development activities phase separate with ownership of assets; 2) The liquidity of users and business: the use of information technology reduce organization and transportation costs, suppliers and the actual operators no longer limited to same place.

- Virtual: The services and products provided by the digital economy are related to the data stored in their server or system, unlike industry must have a physical product; 
- Multidimensional business model for interactive use: multi-level market business model allows multiple groups to interact through an intermediary or platform; on the one hand these groups may be in a different jurisdiction. And generally has a high external aspect between traders;

- High added value: digital products and services content higher technology, the higher its value, and usually the value added and cost are not set in proportion Digital products and services is the main investment knowledge and technology, knowledge and technology market supply and demand with the traditional linear supply and demand in the economy is very different, the digital economy is difficult to directly use market pricing strategy;

- Data-dependent: the digital economy use large amounts of data in high-speed computing replace humans gather information and decision-making, which optimizes the new business model, research and development services and products.

It is precisely because of the above characteristics of digital economic transactions, so that digital transactions and ordinary commodity trading patterns are different. BEPS concerns are raised by situations in which taxable income can be artificially segregated from the activities that generate it. In many cases, the nature of the strategies used to achieve BEPS in digital businesses is similar to the nature of strategies used to achieve BEPS in more traditional businesses. Some of the key characteristics of the digital economy may, however, exacerbate risks of BEPS in some circumstances, in the context of both direct and indirect taxation. Therefore, it is necessary to examine closely not only how business models may have evolves in the digital economy, but also how overall business models can be implemented in an integrated manner on international scale from a legal and tax structuring perspective.

\section{Challenges to the Tax Base in the Digital Economy}

\subsection{The Concealment of Taxpayers}

In the digital economy, according to traditional international tax law, to judge whether the international nonresident enterprises have the obligation to pay taxes in the exchange is according to the presence of a permanent establishment in the country market. If non-residents set up a permanent establishment in a country has its obligations to pay taxes. Constitute a permanent establishment usually requires "entities". Due to the virtual nature of the digital economy, the traditional tax rules cannot effectively discriminate permanent establishment. Definition of permanent establishment under OECD is subject to the impact of the current digital economic transactions: 1) according to OECD Chapter 5 Article 1, the definition of permanent establishment needs a fixed location. The digital economy can be traded with a Contracting State in the presence of a virtual nature; 2 ) according to OECD Chapter 5 Article 4 Auxiliary, preparing equipment are excluded from the definition of a permanent establishment, and the digital economy transaction only needs one warehouse to carry on the entire business process; 3) according to OCED Chapter 5 Article 5, if an enterprise trade with other contractual countries through the signature, then the business is considered to have a permanent establishment. But in the digital economy the location of the signing of a commercial contract has lost its importance. This means that the existing "dependent agent PE" is defined obsolete.

\subsection{Erosion of the Tax Base of the Income Tax}

\subsubsection{The Erosion of Income Tax Base}

1) By reducing the function of the market, risk and assets

Under normal circumstances, multinational companies will set up entities in the country major market's country. And in the digital economy, the enterprise could in the market set up permanent establishment and through the design of intangible assets only rarely taxable profits. Because of the digital economy, according to the current law of transfer pricing under the function, the definition of risk and capital market areas under the jurisdiction of the value does not complete response behavior of actual sales, the existing transfer pricing rule will likely result in no profit can be assigned a permanent establishment.

Specific operations are multinational corporations can be assigned functions, risks and assets do not conform to the contract by the actual activities of the parties to the case. And local activities related to assets (especially intangible assets) and possible risks through contractual arrangements assigned to other subsidiaries in low tax environment operations. These intangible assets are often undervalued and claimed their subsidiary corporation 
have its ownership. Therefore, the group's subsidiaries have the right to allocate most of the profits from multinational group. There by stripping profits from high-tax jurisdictions in the market.

2) Eliminate or reduce the parent company's local tax revenue

In international trade, enterprises operating digital products and services to escape the tax of parent company's country as the same as escape the tax of market country. Eliminating or reducing the tax burden on the country where the parent company is mainly avoid CFC rule (CFC rule). CFC rule is about to set up a foreign resident who controlled foreign companies included in the scope of anti-avoidance tax or no tax at a very low tax havens. If the controlled foreign company has a non-rational management needs to allocate or reduce profit distribution. Undistributed profit will be still included in the current income of the resident enterprises, and declare the tax to the tax authorities [1].

Although different CFC rule in different countries, different regions vary, but resulting from the remote supply of digital products and services are usually not included in the scope of taxation law of the CFC. In the digital economy, multinational corporations can establish CFC in a low tax area to acquire such revenue, which can reduce the tax even do not pay taxes. It is usually the core of intangible assets placed in the Controlled Foreign Company, the next use of these intangible assets to sell digital products and remote services. In the low-tax country controlled foreign companies do not even need to engage in other business activities. And transnational group to create profits in the CFC belongs in the jurisdiction only need to pay a small amount of tax even there is no tax liability. And under the operation framework of country of origin and the ultimate controlling parent company where the residents of China has realized the tax avoidance.

3) Avoid abuse of tax withholding tax

If a digital economy company receiving a specific income from non-resident countries (origin) paid by the company, including dividends, interest, royalties, fees, the company, according to the provisions of the tax law, may need to pay withholding tax in non-residence (source) country. The company in accordance with international tax law may require countries to non-residents (source) pre-payment provision for income tax. If payments between the payer and the recipient countries have a tax treaty, then the digital economy companies may get preferential rates or zero rate of withholding tax paid to the source country. In order to achieve the purpose of tax avoidance, the digital economy, companies need to set up a shell company in the middle of a third country, the third state-owned wider preferential tax treaty network but does not have enough provisions to prevent the abuse of tax concessions [2]. Thus BEPS problem arises, for example: a British parent company in Brazil, it has set up a subsidiary in the UK, the British subsidiary if the parent company to the Brazilian Department of dividends, the UK subsidiary of the need to pay a $30 \%$ withholding tax. However, if we consider a shell company set up in the Netherlands, the Netherlands and dividends remitted to shell companies, because Britain and the Netherlands signed a tax treaty, the British subsidiary of dividends paid by the company to the Netherlands provisions pay only $5 \%$ withholding tax. At the same time, the Netherlands is not for its own corporate income tax levy. Through this architecture, the withholding tax is required to pay the UK subsidiary from $30 \%$ down to $5 \%$, thus greatly reducing the overall tax burden.

\subsubsection{The VAT Tax Base Erosion}

Digital Economy trading company having occult and virtualization features, making it difficult to discern the true identity of the tax authorities so as to bring the scope of the value added tax collection and mode of tax collection is difficult to determine. Under the digital economy, tax exempt enterprises (such as the financial services industry) will purchase digital content products to non-resident enterprises that do not levy value-added tax or low tax rate countries

For example, if there is a multinational international bank, the bank in the resident country is a tax exempt enterprise. If the international bank is to purchase services from domestic suppliers, because it is tax-free company, its procurement of services and products are not deductible input tax, it is tantamount to saying that the multinational banks were enlisted "input VAT". Under normal circumstances, the multinational international bank purchasing digital services from the non-resident supplier, to be based in their countries for self-assessing VAT tax, and when self-assessing VAT on the application deduct input VAT, where the VAT levied by the supplier countries, not by the tax-exempt country levy lies. If the supplier-country does not impose vat or value-added tax rate is lower than the national bank where the tax rate, international banks will not be subject to VAT, or only low pay VAT. This produces a tax base erosion problems [3]. This will be detrimental to the country where the supplier of tax-exempt country. Because the tax exempt enterprise host country supplier will 
provide the digital service for the domestic enterprise to collect and pay the value-added tax, and non-resident providers can receive a zero or small amount of value-added tax through tax planning trading architecture.

\section{Measures to Deal with the Tax Avoidance of the Digital Economy}

\subsection{Prevent Artificially Avoid Permanent Establishment}

Although the international definition of permanent establishment vulnerability has already been found, due to the developed countries, leading international tax rules, developed countries as a net exporter of capital and will maintain this trend for a long time. Delaying the definition of permanent body modification will be conducive to the right to tax in the developed countries. Therefore, in 2003, OECD after analyzing the e-commerce still tried to define a standard physical presence as a permanent body, with only slight modifications [4]. If the fixed place of this standard exists. There is no real improvement in the problem of the digital economy tax avoidance.

China is a net importer status of e-commerce, cross-border e-commerce in the international distribution of profits, should continue insisting on a net source of e-commerce tax jurisdiction. Italian tax Prof. Pasquale Pistone put forward a new junction point of the digital economy, and to modify the definition of permanent establishment so that the right to tax profits and the actual market linked to the creation of the country. Professor Pistone very new theory will benefit included in the definition of a permanent establishment, the benefit theory suggests that multinational companies deal with transaction benefiting from a country's transport, energy delivery, public infrastructure, legal system, etc. Then this company should pay tax according to the level of benefit. This modification of the digital economy to modify the definition of a permanent mechanism gives a solid theoretical foundation, but benefited from the controversial theory of multinationals in a country's level of benefit is difficult to specifically measure. His view is that the use of one-third of the profit allocation method profit allocated to no physical presence jurisdiction market. Pistone gave a new definition to the permanent establishment about new junction, and suggested reducing the threshold of a permanent establishment, such as the following indicators: electronic sales, the number of links and the number of users, such as the level of consumption.

The problems of the permanent establishment also need to multi-national cooperation, if unilateral behavior is likely to result in double taxation, which is detrimental to the development of e-commerce. National tax authorities should endeavor to obtain reliable intelligence information can be verified, an international coordinated intelligence data collection system, such as recording format, electronic records, obtain intelligence information and third-party tax collection arrangements. And strive to build a new international tax order to effectively curb tax base erosion and profit-shifting.

\subsection{Avoid the Erosion of the Tax Base}

\subsubsection{Settlement of Income Tax Base Erosion}

1) Using trading profit split method match the distribution of profits and value creation

Digital economy is highly dependent on intangible assets to create value and generate revenue. Intangible assets can be transferred by the price of non - independent transaction principle, thus resulting in profit transfer, mainly due to: a) Intangible assets at the time of transfer is difficult to estimate; b) The asymmetric information between taxpayers and tax authorities; c) certain arrangements make it difficult to identify the hidden intangible assets to free transfer.

Professor Piston proposed tax sources theory key point is to ensure transfer pricing result and value creation closely linked. To resolve multinational transaction price in a non-independent transfer of intangible assets, it is necessary to accurately define the actual transaction, and then determine the transaction price in accordance with the most appropriate transfer pricing method.

"Transfer Pricing Guidelines" state that the transaction is to analyze the profit split method may be highly integrated business model most appropriate transfer pricing method. It is possible to effectively match the profit distribution and value creation under the independent transaction principle. To achieve this, we need to "arm's length principle" relating to functional analysis, risk identification and distribution of the content to be modified. And ultimately make ownership of intangible assets can't enjoy excess returns multinational corporation use of intangible assets acquired. So that ensure the profit distribution of intangible assets is returned to its value.

In order to perform an independent multinational trading price principle, should make the intangible value created by the Group contributions made by that member of the Group for the development of intangible assets, 
enhance the value, maintenance, protection and utilization of functions performed, assets and all assume all risks should receive reasonable compensation: a) Function. It is the focus of the analysis to determine whether a particular company has the ability to exert control over the actual execution of these control functions. Outsourcing firms need to be compensated for their functions in accordance with the principles of independent trading; b) Risk. To take risks and have the right to share the return of enterprises, we should ensure that it does perform to the required functions and to ensure that the cost of the implementation of the corresponding costs to bear the responsibility; c) Assets. we must first distinguish financial risk and operational risks arising, and secondly, there are differences between the funders beforehand expected benefits and returns afterwards actually obtained by funders need to be adjusted.

2) Improve the scope of the attribution rule CFC

Due to the birth of new trading patterns which is about digital products and services. Some of special transactions in China are still not clearly classified, such as remote digital trading and services. Due to the type of transactions cannot be classified clearly bring CFC classification difficult. According to the State Administration of Taxation of Profit issued the "Implementation Measures of Special Tax Adjustments" Article 84, if China's controlled foreign companies meet "main achievements resulting positive business activities", the foreign companies will not be allocated or not allocated to reduce China resident enterprises current period income. On the one hand, the word "main" is ambiguous, and the second, if the remote digital product transactions and service transactions defined service types of transactions, compared with a positive operating income. If the remote digital product transaction and service transaction is defined as the service trade, the income from the active management. If it is defined as the transfer of the franchise, it is a negative operating income. The ownership of the Controlled Foreign Company's income is different. Due to the ambiguity of the provisions of the controlled foreign enterprises can easily lead to circumvent China's tax burden.

China should continue to clearly define the digital products and services, and to consider whether to include the scope of CFC attributable to the parent company. To further prevent foreign parent companies avoiding tax, CFC rules may specify enormous contribution of staff to the sale of products and services to make exceptions for a set.

CFC rules can be set with an exception clause when specific provisions of the work of the sale of products and services to make a great contribution. That is to take a proportional: when revenue/Employee generated more than a certain percentage on the company's products and services included in the transaction of CFC rules.

3) To prevent abuse of tax treaties

As of 2015, China and 99 countries have signed agreements to avoid double taxation, second only to the UK to promote the development of our country on the Chinese market objective. However, driven by economic interests, the ownership of the Controlled Foreign Company's income is different. OECD submitted a Plan of Action Item 6 "to prevent improper granting of preferential tax treaty" in September 2014, which is one of the most important actions BEPS issue [5]. The action plan is to reduce tax evasion and tax avoidance under the premise of eliminating double taxation. It made the following efforts: eliminate double non taxation is not the intent of the tax treaty, and determine the tax policy considerations that should normally be carried out prior to the conclusion of a tax treaty between the countries and their countries.

Important implication for our country is that in international practice international tax level is higher than the domestic tax law. International tax treaties provisions designed to eliminate double taxation, but if the result is the case of double non taxation, the OECD believes that may refuse to give tax treaty benefits, so as to ensure market dependency can not to be bound by the terms of agreement of the international tax and the implementation of the domestic law, which to solve the international double tax avoidance has far-reaching significance [6]. For the following two situations: a) foreign companies claim they don't have permanent establishment of taxable entities in other country; $b$ ) if foreign companies have permanent establishment of taxable entities in other country, but the relevant amount deductible payments project is too large. In these cases the state of the market country can be processed in accordance with domestic law withholding tax [6]. When judging a company's abuse of a tax treaty, tax authority should pay attention to their "real business purpose", the operating principle of the use of the substance and avoid losses of tax revenue in the international area.

\subsubsection{Solve the Problem of Tax Avoidance VAT}

In order to solve the problem of VAT tax evasion, and promote fair competition between domestic suppliers and non-resident suppliers, the problem of value added tax collection and management of digital economy transac- 
tion should be solved urgently. On the one hand, the article "tax framework conditions" clearly stipulates digital product transaction should be recognized as a service rather than sales of goods. The BEPS 2014 suggested that taxation right of digital products and services should be given to the jurisdiction of the buyer's location, and the country's enterprises should, in accordance with the local rules, self-assess the value added tax on the intangible assets of the remote service. OECD in 18 December 2014 published the draft for the global e-commerce VAT Guide mode discussion paper, and countries are trying to make all the countries in the world in any case the number of economic transactions reached a consensus on the principle of consumption. From our point of view, China is actively promoting the "camp changed to increase" cross-border goods and services will be unified VAT [7]. Under the existing "Business Tax", our country takes the principle of consumption and the principle of origin at the same time. This will conflict with OECD tariff. This may bring potential indirect tax double taxation problem, and our country should be combined with "camp changed to increase" the opportunity, actively solve the problem of cross-border coordination of China's value-added tax international tax.

On intangible assets and transaction services between B2B, the article "tax framework conditions" considers that when companies go overseas to purchase digital services and products, their own assessment methods and the assessment of the mechanism of tax assessment method can protect the competitive position of domestic suppliers, but also to protect the tax base from erosion [8].

In addition, e-commerce $\mathrm{B} 2 \mathrm{C}$ model, providing services to non-residents and consumer services and rely on self-assessment of ways to implement the destination principle; in the course of practice isn't easy to cause the phenomenon of widespread non-taxation, because B2C and B2B model have different process. The tax awareness and the tax compliance of individual consumers to voluntarily declare are low [9] [10]. In this regard, the self-assess- ment tax change to establish by the labor service providers to collect and remit the mechanism may be a feasible method [11].

\section{Enlightenment and Prospect}

Due to the particularity of the Digital Economy Trade: Trade in cyberspace, there is no tangible copy of the contract document. To track the resulting income trading position and make sure it is sales revenue, service income, use fee or other types of income, is also very difficult. The development of new technology has increased the possibility of tax planning for tax avoidance in this field. With the development of digital economy, the tax base continues to be eroded, especially in the near future. It can be expected that more and more traditional business transactions will gradually shift to digital economy.

Faced with the challenges of international, tax authorities shall promptly cooperate with their respective governments and international organizations to develop policies and protocols. Policy direction is to modify the definition of a permanent establishment of the digital economy; clear intangible assets and the use of risk transfer arrangements in the transfer pricing rules; refinement $\mathrm{CFC}$ rules.

\section{References}

[1] Leng, C.Q. (2012) The Research on the Application of the Permanent Establishment Rule to Electronic Commerce. Shanghai Jiao Tong University, Shanghai.

[2] Owens, J. (2014) After BEPS Era and the Impact on China. International Tax.

[3] Liang, Y.C. and Liu, X.J. (2009) Review of the Capital Weakening Tax System. International Taxation.

[4] Wu, Z.X., Zhao, L. and Huang, D. (2014) An Anti-Avoidance Research on Transfer Pricing of Cross-Border Transaction of Intangibles. International Tax.

[5] Liao, Y.X. (2010) Case from Glaxo Marketing of Intangible Transfer Pricing Regulation Issues. Lawyer.

[6] Guo, X.J., Zhang, B. and Gao, L.Q. (2015) Challenges and Strategies for International Taxation in the Digital Economy. International Tax.

[7] OECD (1998) Electronic Commerce: Taxation Framework Conditions. OECD, Paris, Oct. Framework Conditions c, 5-8.

[8] OECD/G20 (2014) Base Erosion and Profit Shifting Project. Developing a Multilateral Instrument to Modify Bilateral Tax Treaties, Action 15: Deliverable.

[9] OECD (2013) Action Plan on Base Erosion and Profit Shifting. OECD Publishing. http://dx.doi.org/10.1787/9789264202719-en 
[10] OECD (2015) Aligning Transfer Pricing Outcomes with Value Creation. OECD Publishing.

[11] Hongler, P. and Pistone, P. (2015) Blueprints for a New PE Nexus to Tax Business Income in the Era of the Digital Economy. WU International Taxation Research Paper Series. 